\title{
The Relationship between Manager's Decision Making Styles and Teachers Empowerment in Saveh Primary
}

\section{School}

Khadijeh Jokar ${ }^{1}$,Davoud Hosseinzadeh Ph.D ${ }^{2}$,Amir Hosain Mohammad Davoudi ph.D ${ }^{3}$

${ }^{1}$ Department of Management, College of Human Science, Saveh Branch, Islamic Azad

University, Saveh, Iran. (Email: jokar_ida@yahoo.com)

${ }^{2}$ Department of Management, College of Human Science, Saveh Branch, Islamic Azad

University, Saveh, Iran. (Email: dhosseinzadeh@yahoo.com)

${ }^{3}$ Department of Management, College of Human Science, Saveh Branch,Islamic Azad

University, Saveh, Iran. (Email: adavoudi838@yahoo.com)

Doi:10.5296/ijhrs.v4i4.6714 URL: http://dx.doi.org/10.5296/ijhrs.v4i4.6714

\begin{abstract}
The present research was conducted to find out the relationship between manager' $s$ decision making styles and teachers empowerment in primary schools of Saveh city. Research methodology of the study from the perspective of data collection in descriptive and correlation and from the perspective of purpose is a practical one. The population of the study consisted of all the teachers of Saveh primary school. Based on Morgan's Table، a sample size of 211 persons was determined and the samples were randomly selected through relative stratified method. Data collection tools were two standard questionnaires of decision making style Scott \& Bruce، consisting of 25 items and psychological empowerment Spritzer questionnaires containing 20 items in five -point Likert scale. The content validation of each of the two questionnaires were confirmed by the specialists and their reliability calculating Cronbach s coefficient alpha were respectively 0.75 and 0.88 . The datacollected through descriptive and inferential statistics، like Kolmogorow-Smirnov test، pearson correlation coefficient، regression and step by step analysis were analyzed through the statistical software SPSS. The results of the study reveal that there is relationship between manager' $s$ decision making styles and teachers empowerment. in such a way among the predictive variable dimensions،only " rational and avoidant Decision Making style" were on the model.Considering the results of the study ' there is a significant positive relationship between rational decision making style and empowerment. There are significant negative relationship between avoidant and spontaneous decision making styles and empowerment. There aren't relationship between intuitive and avoidant decision making styles and empowerment.
\end{abstract}

Keywords: decision making styles، empowerment، teachers 


\section{Introduction}

Today, with the progress of science and technology, communities to become more complex and specialized. organization of educational institutions, especially in the community are no exception. The outcome of this process more specialized and complex, is creating a world full of competition. In this present competitive world, organizations for their survival have changed their structure or to be equipped with the tools to deal with global developments. The most important factor to earn a productivity in organizations and schools, is a human function and thereby that the school authorities should pay special attention to employee education. One of the factors that, in order to improve the performance of human resources has been raised is staff empowerment.(Ziyaei \&Ibaghi ,2008)

The term empowerment of human resources, as a new internal motivation approach ,to the meaning of the motivational releasing the inner forces of the staff and to provide a platform, and to opportunities for prosperity, talent, ability and competence of the people. Empowering starts within change in beliefs, thoughts and how staff treat.(Jafaei,2012)

The first operational definition of empowerment in 1988 was provided by Conger and Kanango. In a study that was done by Spritzer(1995), was raised four basic dimensions for empowering. later research of Mishra(1992) another side on these dimensions added that include: feelings of competence,self-determination, a feeling of being effective,the feeling of having to trust others and significant sense (being valuable) the can be found.(Hazrati,2008)

Several factors such as show the leader's commitment to the staff, staff training, quality teams to work, the participation of employees in the planning and sharing information and delegation affect to human resources empowering.(Naderi,2008) But seems one of the most important variables influencing employee empowerment to be manager' s decision making styles.

The decision making is one of the controversial issues in organizations and managers are constantly faced with decisions. In this regard, Estoner believes that "the decision is a process by which a specific action method for solving special problems can be selected. Decision making is important as the main essence in the all managers tasks.

Scott and Bruce (1995) in their studies on the factors affecting decision making styles and more features, has a lot of attention to internal features and individual differences and on the basis of have presented five decision making style under the title of General decision making styles. (Parker \&et al, 2007)

So the need to empowerment and pay special attention to as the criteria in the success of the Organization and the right decisions for empowering employees to be felt. This research would be able the lead to recognize and understand more the concept, dimensions and other factors associated with the decision of the administrators and empowerment. In the present study the issue will be examined to what extent the manager' $\mathrm{s}$ decision making styles that is one of the most important practices of managers, are related to teachers empowerment.

Decision making is the most important and basic task management and can be raised at all levels and organizational categories, although pundits science management express tasks for administrators, but as Herbert Simon as a management scholar has "the process of decisionmaking is the essence of all of the management".

After years of experience, the world concluded that if an enterprise wishes to work in 
leading economics and finance,and did not back in the sphere of competition need specialized manpower, creative and highly motivated to be very high. Real wealth is based on a human resources make up the organization. Is a prerequisite for achieving the objectives of the Organization, effective management of these resources is valuable. In this regard, growth, progress, prosperity and enhancing the capabilities of employees in recent years as to empower the staff respected experts in human resource management is located. (Naderi, 2008).

Empowerment is a key strategy to organization expand and adapt to the changes. In today's work environment needs to employees that can be able to decide, the solution provider and be accountable in front of their work.Therefore, this field is updated in the inner and innate empowerment, but admitted to an appropriate growth and sound effects and show it.(Tavanaei,2008)

\section{The definition of employee empowerment}

Poissant,define empowerment as the involves the strengthening of staff skills and building confidence in them to themselves and trying to the effectiveness of the central organization.(Shahraki,2010)

Conger and Kanango, of these pundits believe,empowerment is the process of increasing the adequacy of self-confidence of the organization identify and introduce conditions that cause a lack of enjoyment of the power in them.(Abtahi and Abeci,2008)

\section{Dimensions empowerment}

Spritzer (1995) in its research studies, has measurement four dimensions and he has credibility finding.Veton and Cameron(1998) on the basis of research carried out by Mishra(1992) added dimensions of trust to it. Therefore, based on the past research, the psychological empowerment will be five dimensions.

Competence: Competence(self-efficacy) consisted of an individual's belief human capability to perform activities with skill.

Self-determination: Is an individual's sense of having choice in initiation and regulating actions.

Impact: Impact is the degree to which an individual can influence strategic, administrative or operating outcomes at work.

Meaning: Meaning is the value of a work goal or purpose, judged in relation to an individual's own ideals or standards.

Trust: Is an individual's sense of that with the same behavior, they will be fair.(Saleh,2010)

\section{The definition and nature of the decision}

When there was a choice of human sight, there is also a decision .John Dewey in 1910 for the first times has pointed out the decision process (Gholi pour, 2009). Anatomy of the decision making process is, in fact, that through it the way it is a significant selection of 
problem solving. In the process of selection of a different ways to resolve an issue is choice. (Rezaeian, 2008, 57)

\section{Public decision making styles}

Unlike many pundits to emphasize environmental factors and the enterprise as the main factors influencing the choice of peoples decision making style, Scott and Bruce are taken into consideration more individual and inner characteristics of people as important factors in the formation of the style of the decision. On this basis, they have raised five different styles to make decisions with respect to, peoples internal differences .

Rationl: This style expresses the tendency for decision-making to identify all possible approaches, evaluation of the results of all the different aspects of each solution, and finally choosing the optimal solution and optimal decision-making when faced with the decision, respectively.( Scott and Bruce, 1995)

Intuitive: In this style when individual faced the decision conditions, trust your inner vision and strategy and selects right solution that seems more correct.

Depended: This style is indicative of the lack of intellectual and practical independence of decision-making and guidance on the protection and support of others when making decisions.

Avoident: In this style individual when facing the question as much as it is that the decision to suspend prizes or through unleashed problem and any rebound will dodge the process of occurred.

Spontaneous: Individual when faced with the position of the decision, immediately and promptly adopt their main decision.(Tabesh,2012)

\section{Research performed}

Hushmandi (2013), did a study entitled "the relationship between the administrative decision making styles and organizational health in kazeroun city government agencies". The findings of the research showed that between organizational health and avoidance, rational and dependent decision making style at the level of $99 \%$ and between organizational health and intuitive and spontaneous decision making style and employee job experience at the level of 95 percent,there is a significant relationship.

Ghasemi Madani(2011), did a study entitled "the relationship between the cultural intelligence and administrators decision making style in middle school ". The research results showed that: there is a significant relationship between cultural intelligence and rational, intuitive and spontaneous decision making styles.

Nick akhlagh(2013) did a research entitled "the relationship between the leadership team with organizational learning and teachers empowerment. The results showed that there is a significant relationship between team leadership with organizational learning and Secretaries empowerment. The leadership team is the empowering effect only indirectly and through the intermediary variables of organizational learning.

Hajizadeh (2012)did Research entitled "the relationship between the characteristics of servant leadership style and teachers empowerment ". The results showed that there is high and positive relationship between servant leadership and empowering. 
Huang (2012)did the research titled "the role trust to administrator in psychological empowerment, receive feedback and job performance". The results of this study, the support process model that puts psychological empowerment, trust administrator, feedback and job performance are linked to each other, in particular there was a positive communication between psychological empowerment and the Trust administrator .

Salo (2011)did the research under the heading "decision making styles, gender and stress among the police force ". The results showed that there is a positive relationship between the style of decision-making and decisions associated with avoidance performance-based selfesteem.

Gill and et al (2010) did the research under the title "the relationship between distributive leadership and empowerment with job satisfaction". Positive relationships between i) employee perceived transformational leadership used by managers and employee perceived job satisfaction and ii) employee perceived empowerment and employee perceived job satisfaction were found.

Baiocco(2009), did a study with the title " decision-making style among adolescents: relationship with sensation seeking and locus of control". The results showed that older adolescents used more rational decision making style than younger ones and lower means scores on intuitive, avoidant and spontanous scales.

Considering the past researchs and according to the definitions provided, offered the following conceptual model for how to connect the research variables.

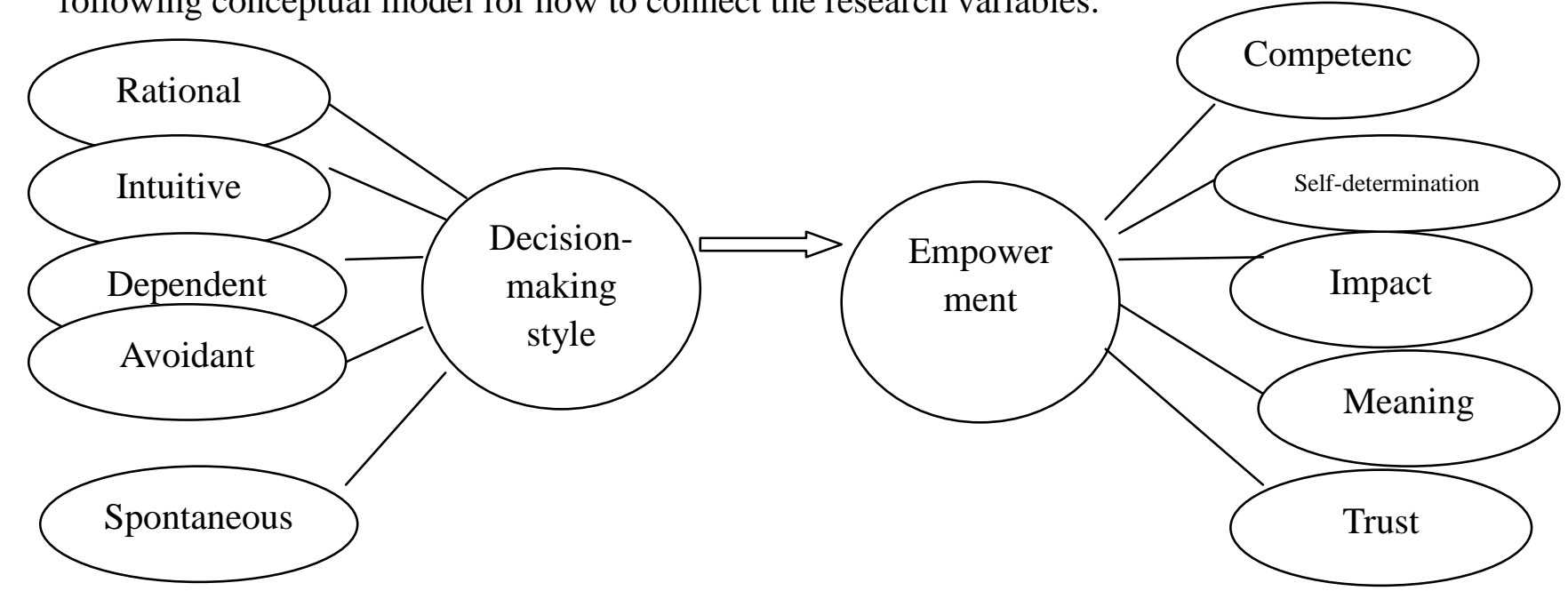

\section{Figure(1)Conceptual model of Relationship Between Decision Making Styles and Empowerment}

Accordingly, the following hypothesis is formulated:

The main hypothesis: There is a relationship between manager' $\mathrm{s}$ decision making styles and teachers empowerment in Saveh primary school

\section{Alternative Hypothesis}

H1: There is a relationship between intuitive decision making style and empowerment.

H2: There is a relationship between rational decision making style and empowerment. 
H3: There is a relationship between dependent decision making style and empowerment.

H4: There is a relationship between avoidant decision making style and empowerment.

H5: There is a relationship between spontaneous decision making style and empowerment.

\section{Methodology of research}

Research methodology of the study from the perspective of data collection in descriptive and correlational and from the perspective of purpose is a practical one. The population of the study consisted of all the teachers of Saveh primary school. Based on Morgan's Table، a sample size of 211 persons was determined and the samples were randomly selected through relative stratified method. It should be noted that finally collect 196 questionnaire. Data collection tools were two standard questionnaires of decision making style Scott \& Bruce، consisting of 25 items and psychological empowerment Spritzer questionnaires containing 20 items in five -point Likert scale. The content validation of each of the two questionnaires were confirmed by the specialists and their reliability calculating Cronbach s coefficient alpha were respectively 0.75 and 0.88 . The datacollected through descriptive and inferential statistics‘ like Kolmogorow-Smirnov test‘ pearson correlation coefficient‘ regression and step by step analysis were analyzed through the statistical software SPSS.

\section{The findings of the research}

H1: There is a relationship between intuitive decision making style and empowerment. Table (1) correlation matrix between intuitive decision making style and empowerment $(\mathrm{n}=$ 196)

\begin{tabular}{|l|l|l|}
\hline empowerment & intuitive & \\
\hline $\mathrm{r}=0 / 033$ & 1 & intuitive \\
\cline { 1 - 1 } $\mathrm{P}=0 / 32$ & & \\
\hline 1 & $\mathrm{r}=0 / 033$ & empowerment \\
\cline { 2 - 2 } & $\mathrm{P}=0 / 32$ & \\
\hline
\end{tabular}

As table(1) shows, significant level between the two variables is greater than $0 / 05$. Thus, it can be conclude that there isn't a relationship between intuitive decision making style and empowerment.

H2: There is a relationship between rational decision making style and empowerment.

Table (2) correlation matrix between rational decision making style and empowerment $(\mathrm{n}=$ 196)

\begin{tabular}{|l|l|l|}
\hline empowerment & rational & \\
\cline { 1 - 1 } $\mathrm{r}=0 / 330$ & 1 & rational \\
\cline { 1 - 1 } $\mathrm{P}=0 / 01$ & & \\
\hline 1 & $\mathrm{r}=0 / 330$ & empowerment \\
\cline { 2 - 2 } & $\mathrm{P}=0 / 01$ & \\
\hline
\end{tabular}

Based on the information table (2) the relationship between two variables is significant at the level of $0 / 01$. Thus, it can be concluded that with 99 percent confidence there is a positive and significant relationship between rational decision making style and 
empowerment.

H3: There is a relationship between dependent decision making style and empowerment. Table(3)correlation matrix between depended decision making style and empowerment $(\mathrm{n}=$ 196)

\begin{tabular}{|l|l|l|}
\hline empowerment & dependent & \\
\cline { 1 - 1 } $\mathrm{r}=-0 / 077$ & 1 & dependent \\
\cline { 1 - 1 } $\mathrm{P}=0 / 14$ & & \\
\cline { 1 - 2 } 1 & $\mathrm{r}=-0 / 077$ & empowerment \\
\cline { 2 - 3 } & $\mathrm{P}=0 / 14$ & \\
\hline
\end{tabular}

As table(3) shows, significant level between the two variables is greater than $0 / 05$. Thus, it can be conclude that there isn't a relationship between dependent decision making style and empowerment.

H4: There is a relationship between avoidant decision making style and empowerment. Table(4)correlation matrix between avoidant decision making style and empowerment $(\mathrm{n}=$ 196)

\begin{tabular}{|l|l|l|}
\hline empowerment & avoidant & \\
\cline { 1 - 1 } $\mathrm{r}=-0 / 351$ & 1 & avoidant \\
\cline { 1 - 1 } $\mathrm{P}=0 / 01$ & & \\
\cline { 1 - 2 } 1 & $\mathrm{r}=-0 / 351$ & empowerment \\
& $\mathrm{P}=0 / 01$ & \\
\hline
\end{tabular}

Figures obtained from the table (4) shows that there is a negative relationship between avoidant decision making style and empowerment.

H5: There is a relationship between spontaneous decision making style and empowerment.

Table(5)correlation matrix between spontaneous decision style and empowerment $(\mathrm{n}=196)$

\begin{tabular}{|l|l|l|}
\hline empowerment & spontaneous & \\
\cline { 1 - 1 } $\mathrm{r}=-0 / 165$ & 1 & spontaneous \\
\cline { 1 - 1 } $\mathrm{P}=0 / 01$ & & \\
\hline \multirow{2}{*}{1} & $\mathrm{r}=-0 / 165$ & empowerment \\
\cline { 2 - 2 } & $\mathrm{P}=0 / 01$ & \\
\hline
\end{tabular}

The results table (5) shows that relationship between two variables is significant at the level of $0 / 01$. Thus, it can be concluded that with 99 percent confidence there is a negative and significant relationship between spontaneous decision making style and empowerment.

Main hypothesis: There is a relationship between manager's decision making styles and teachers empowerment in Saveh primary school.

Table (6)summary of multiple regression analysis to examine the relationship between decision making style and empowerment. 


\begin{tabular}{|l|l|l|l|l|l|l|}
\hline $\begin{array}{c}\text { Significant } \\
\text { level }\end{array}$ & $\Delta R^{2}$ & $\begin{array}{l}\text { Adjusted } \\
\text { correlation }\end{array}$ & $\begin{array}{l}\text { Square of the } \\
\text { correlation } \\
\text { coefficient }\end{array}$ & $\begin{array}{l}\text { The } \\
\text { correlation } \\
\text { coefficient }\end{array}$ & $\begin{array}{l}\text { Predictor } \\
\text { variables in the } \\
\text { model }\end{array}$ & Model \\
\hline $0 / 01$ & $0 / 123$ & $0 / 119$ & $0 / 123$ & $0 / 351$ & $\begin{array}{l}\text { avoidant decision } \\
\text { making style }\end{array}$ & 1 \\
\hline $0 / 01$ & $0 / 051$ & $0 / 166$ & $0 / 174$ & $0 / 417$ & $\begin{array}{l}\text { Rational decision } \\
\text { making style }\end{array}$ & 2 \\
\hline \multicolumn{7}{|c|}{ Criterion variable: empowerment } \\
\hline
\end{tabular}

Based on the information table (6), of the 5 Predictor variable " only 2 variable "avoidant decision making style" and "Rational decision making style" have been entered into the model. Avoidant decision making style, approximately explained 12.3 percent variation to teachers empowerment.In model 2, When the "Rational decision making style" will be added to the model,

approximately 17.4 percent of the variance teachers empowerment, explained by linear relationship with variables"avoidant and Rational decision making styles".

Table (7)coefficients of manager' $s$ decision making styles in prediction teachers empowerment

\begin{tabular}{|l|l|l|l|l|l|l|}
\hline $\begin{array}{c}\text { Significant } \\
\text { level }\end{array}$ & $\mathrm{T}$ & $\begin{array}{c}\text { Coefficients of } \\
\text { standardized } \\
\text { variables } \\
\text { (Beta) }\end{array}$ & SE & B & model & $\begin{array}{l}\text { Predictor } \\
\text { variables in the } \\
\text { model }\end{array}$ \\
\hline $0 / 01$ & $19 / 1$ & & $3 / 8$ & $73 / 06$ & $\begin{array}{c}\text { 1-Latitude } \\
\text { of origin }\end{array}$ & \\
\hline $0 / 01$ & $-4 / 08$ & $-0 / 280$ & $0 / 164$ & $-0 / 67$ & $\begin{array}{c}\text { variable } \\
\text { coefficie } \\
\text { nt }\end{array}$ & $\begin{array}{c}\text { avoidant decision } \\
\text { making style }\end{array}$ \\
\hline $0 / 01$ & $3 / 5$ & $0 / 237$ & $0 / 249$ & $0 / 861$ & $\begin{array}{c}\text { variable } \\
\text { coefficie } \\
\text { nt }\end{array}$ & $\begin{array}{c}\text { Rational decision } \\
\text { making style }\end{array}$ \\
\hline
\end{tabular}

Based on the existing data in the table, can be write the regression equation as followes:

Predicted empowermen $(\mathrm{Y})=-0.280$ (avoidant decision making style) +0.237 (Rational decision making style)

On the basis of the above regression model can be said with the increase of one standard deviation of the "rational decisions" managers of primary schools the size of 0.237 standard deviation is added to the empowerment of teachers in these schools and with the increase of one standard deviation of the "avoidant decisions" managers size of 0.280 standard 
deviation of "empowering" teachers will be eased.

\section{Discussion and conclusions}

Organizations as open systems interacting with their environment and for continuity of life need to respond the environment changes. Since human resources the most important factor and is the centerpiece of the organization, equip and prepare these resources for to deal with the changes, is the of Special importance .

According to the findings of the research from the perspective of elementary teachers there isn't a relationship between intuitive decision making style and empowerment. The result of this research are consistent with research Amirinezhad(2013) and are inconsistent with researchs Hushmandi(2013) and Gill and et al (2010). The cause of this inconsistent can be not the same statistical community and the nature of the variables considered.In the intuitive decision making style, when managers confronted with the decision, trust on their emotions, instincts and inner vision.In other words, in many other situations, including situations of ambiguity and uncertainty could not be based on purely rational approach to examine all and choose the optimal solution, therefore, in these circumstances rely on your inner vision, and his opinion is more correct approach that selects knows .

Another of the findings of the research showed that there is a positive and significant relationship between rational decision making style and empowerment. The result of this research are consistent with research Hushmandi(2013),Nickakhlsgh(2013) and Baiocco(2009).Managers that use rational style ,making decisions based on your search and full and comprehensive analysis of all available information from the internal resources and external resources and causes of the increasing employees' sense of responsibility and motivation and of corporate social responsibility through their participation in decision making and ultimately choose the best decision from among the options available.

The results of the research showed there is no relationship between dependent decision making style and empowerment. The result of this research are consistent with research Ghasemimadani(2011) and are inconsistent with researchs Nickakhlsgh (2013). The cause of this inconsistent can be not the same statistical community and the nature of the variables considered. Managers that use dependant style, rather than consult with others when making important decisions, and ultimately are the final decision, behavior relies on the opinions of other people. So they need to identify methods and strategies related to building partnerships and for major decisions, held community meetings and use participatory decision-making and teachers collaboration. As well as in schools paid attention to the peoples skills and expertise and increase the capacity of the scientific.

According to the findings of the research there is a negative relationship between avoidant decision making style and empowerment. The result of this research are consistent with research Hushmandi (2013) and are inconsistent with researchs Ghasemimadani(2011). Managers that use avoidant style, when facing the question as much as it is that the decision to suspend prizes or through unleashed problem and any rebound will dodge the process of occurred. So it have to change the culture, behavior and leave the old habits, create a very strong relationship between the manager and staff and given interfere and comment and participate in the tasks to employees and with granting decision-making authority to 
employees, to increase their efficiency and to better play the role of organizational.

Also, research results showed that there is a negative and significant relationship between spontaneous decision making style and empowerment. The result of this research are consistent with research Ghasemimadani(2011), Gill and et al (2010) and are inconsistent with researchs Baiocco(2009). The cause of this inconsistent can be not the same statistical community and the nature of the variables considered. Managers that use spontaneous style , when faced with the position of the decision, immediately and promptly adopt their main decision. Therefore, managers should be looking for opportunities to expand and develop the role and tasks and participatory fields of their staff and with the creation of a common purpose between the staff and their, to refrain from quick decisions issues.

In the end, according to the findings of current research and theoretical research can be concluded that managers are using the correct and rational decision-making style, and avoiding avoidante and spontanous decisions can cause increased the teachers empowerment. Therefore, recommended to education officials and school administrators that with hiring qualified applicants with the best conditions in the learning environment, upgrade decisions fair and equal manner, authority and demonstrate trust in teachers, consider empowering staff in anticipated in-service training, production and distribution leaflets in relation to the stated benefits and long-term results from managers and teachers empowerment, provide opportunities to empower their employees and through it help to the improvement and success of schools, basic changes in working conditions and Promote the needs of employees from levels of biodiversity needs to self-actualization.

\section{Resources}

Abtahi.H \& Abeci. S. (2008) Staff Empowerment. Branch: Management and Research Institute.

Baiocco, R \& Fiorenzo,L. (2009) . Decision Making Style among adolescents: Relationship with sensation seeking and locus of control. Journal of Adolesence.32, 963-967 .

Haji Zadeh,S(2012)The relationship between the characteristics of servant leadership style and teachers empowerment .Journal of educational administration and leadership. Year VI, issue 4, 99-81.

Hazrati, M. (2008). The impact of servant leadership on organizational trust and staff empowerment at government agencies. Master thesis. School of management. The University of Tehran.

Ghasemi madani.SH (2011) The relationship between cultural intelligence and administrators decision making style in middle school. The first National Conference on cognitive science findings on education. 339-319.

Gholi pour.A (2009)The impact of servent leadership on organizational trust and staff empowerment in government organizations. Journal of public management. Volume 1, number 2, 188-103. 
Gill, A\& Flaschner, A, B \& Bhutani, S. (2010). The Relations of Transformational Leadership and Empowerment with Employee Job Satisfaction: A study among Indian Restaurant Employees . Business and Economics Journal. BEJ-3. Retrieved from http://astonjounals.com/bej

Huang . J . (2012) . Be proactive as Empowerd? The Role of Trust in one's supervisor in psychological Empowerment. Feedback Seeking and job performance . Journal of Applied Social Psychology . Wiley periodicals. Inc .

Hushmandi.R(2013) The relationship between the administrative decision making styles and organizational health in government agencies kazeroun city. Master thesis. The free University. Science and research unit Boyer Ahmad.

Jafaei.F (2012) The relationship between team work with the empowerment staff in Organization at Tehran municipality, region 8. Master thesis. The free University. The unit of Saveh.

Naderi.N (2008) Empowerment of employees through in-service training. Research of Humanities and social sciences special management. Number 27, 132-113.

Nickakhlagh.S(2013)The relationship between the leadership team with organizational learning and teachers empowerment in secondary schools. Master thesis. The free University. The unit of Saveh.

Parker , A. M\& Bruine, B , W \& Fischhoff , B.( 2007). Maximizers versus satisficers: Decision-making styles, competence, and outcomes. Journal of Judgment and Decision Making, vol. 2, no. 6, December. , p 344 .

Rezaeian.A(2008). Principles of organization and management. Tehran.

Salo,I\& Allwood ,C.M .(2011) . Decision Making Styles, stress and gender among investigators, policing : An International Journal of Police Strategies andManagement . Vol 34 (1), 97-119.

Shahraki.A (2010)The role of managers in enhancing employees ' capabilities. Master thesis. The University of Tehran.

Tabesh.F\&Zare.H(2012) The impact of emotional intelligence skills training on rational decision making style, intuitive, avoidance, and Annie. Journal of the science of behavior. Volume 6, number 4, 329-323.

Tavanaei.E (2008) Attitude of primary and middle school teachers, cross-organizational culture and its relationship with the extent of their capabilities. Master thesis. Ferdowsi University of Mashhad.

Ziyaei.M\&Nargesian.A\& Ibaghi.S (2008)The role of spiritual leadership in staff empowerment. University of Tehran. Journal of public management. Volume 1, number 1, 89-71. 